Athens Journal of Mass Media and Communications

Volume 7, Issue 4, October 2021 - Pages 239-256

\title{
Soviet Politics and Journalism under Mikhail Gorbachev's Perestroika and Glasnost: Why Hopes Failed
}

\author{
By Dmitry Strovsky ${ }^{*} \&$ Ron Schleifer ${ }^{ \pm}$
}

\begin{abstract}
The terms perestroika (literally, "transformation") and glasnost (literally, "transparency") refer to the social change that took place in the Soviet Union in the late 1980s. Then USSR leader, the General Secretary of the Central Committee of the CPSU, Mikhail Gorbachev, introduced perestroika as a necessary action to improve the nation's economy and its international relations. Glasnost was meant to promote effective discussions regarding the country's existing problems and shortcomings. However, only a few years following their instatement, both processes did not improve the sociopolitical situation. On the contrary, they led to the country's collapse. This article seeks to answer why gracious intentions, meant to actualize the hopes and dreams of the Soviet people, eventually resulted in tremendously difficult times. Special attention is paid to the role of the Soviet media, which became a catalyst for many social problems. The authors raise the issue of the media's level of responsibility during this social transformation, which appeared to be one of the most crucial conditions for its successful implementation.
\end{abstract}

Keywords: authoritarian culture, social transformation, civic society, perestroika, glasnost, Soviet media

\section{Introduction}

Social transformation is a complex phenomenon achieved by shifting traditional features of a country's evolution and adopting new political insights (Harvey, 1989; Blumler and Gurevitch, 1995; Coleman, 2001). It aims to change both the existing system of governmental management and the relationship between all political actors participating in it (Kelle and Koval'zon, 1981). It is a long process dealing with diverse social trends, and therefore such transformation cannot occur overnight; it usually takes several years or even decades. Qualitative changes influencing the interactions between government and society unquestionably affect all spheres of life (Lamazhaa, 2011, p. 262).

Social transformation is sparked by a state of crisis and can succeed only if both the country's political elite and population cooperate. As history demonstrates, if only one side promotes the new system, radical social changes will unlikely develop (Featherstone and Lash, 1995). Both sides may have totally different ideas about why they require transformation, but at a certain stage, through negotiations or intuitively, they must agree on its importance. Otherwise,

\footnotetext{
*Research Associate, Research Center for Defense and Communication, Ariel University, Israel. ${ }^{ \pm}$Senior Lecturer, Research Center for Defense and Communication, Ariel University, Israel.
} 
social transformation will inevitably drown in a heap of unresolved problems (Martinelli, 2012; Brown, 2017).

Both successful and failed social transformations have occurred throughout the twentieth century. Among the former is, for instance, the reorganization of the sociopolitical system in Eastern and Central European countries in the 1980s and 1990s, based on the rejection of the authoritarian system of management. By the early years of these transformations, the seemingly solid and unchangeable sociopolitical foundation of autocracy (being a replica of the existing political system in the USSR) gave rise to remarkable changes, including freedom in various spheres of life, as well as a variety of political institutions, parties, and media being independent of the state system. New political institutions created 30 years ago still exist successfully today.

However, such successful social transformation has not taken place in all modern countries. A much more complex situation emerged in the second half of the 1980s in the Soviet Union, during the years of Mikhail Gorbachev's perestroika and glasnost. Since their introduction into the public lexicon in the mid-1980s, these two concepts have been inseparable. From the start, perestroika referred to changes in the economic mechanism in the Soviet Union, due to the understanding of Mikhail Gorbachev and his inner circle that the pace of the country's development was significantly behind that of the rest of the world. It was intended to more actively use science and technology, decentralize the management of the national economy, expand the rights of enterprises, introduce self-financing, and boost production.

Glasnost, in turn, was intended to promote these changes, with the development of criticism and self-criticism. Glasnost involved eliminating ambiguities in media coverage, and was also meant to ease censorship and increase access to broader sources of information. Consequently, the Russian media began discussing a new course of social development for the country, which led to the public's eventual acceptance of these ideas (Baturin et al., 1989; Afanasyev, 1991).

The public transformation, which occurred in the country from 1985 to 1991, without overestimation changed the minds of millions of people (Sazanov, 2012). It also quite quickly led to the fall of the Iron Curtain between the USSR and Western countries, and subsequently, already in the 1990s, to market reforms in Russia as being the successor of the USSR.

Perestroika and glasnost had enormous social and political consequences in the USSR and far beyond. In the new conditions, private property was legalized, stock and currency markets were created, and a large number of entrepreneurs appeared from seemingly nowhere. Terms such as democracy, plurality, and media freedoms were being perceived in fundamentally different ways than before, which eventually led to the adoption of the new Constitution of the Russian Federation and a number of other laws that ensured the country's qualitatively new political development (Richter, 2002).

However, the main problem of this fundamental social transformation was the lack of a stable state political governance (Turpin, 1995; Oates, 2001). The 1990s, the first post-perestroika decade in Russia, confirmed the existence of a huge number of unresolved issues that had already been identified during Gorbachev's 
tenure. The Soviet leader simply did not know how to solve them in the current conditions, which gradually became a large-scale crisis. One of the most obvious hardships was conspicuous instability of the then economic development and soaring inflation, which caused dire impoverishment of the country's populace (Isakov, 1998). The improvement of life numerously promised by the first Russian president, Boris Yeltsin, was not realized either. The country's domestic policy was perceived by most of its people as anti-national and antidemocratic. Two wars initiated by Russia in Chechnya also affected a sharp drop in Yeltsin's popularity rating. Russian society demanded that order be restored to the country and desired a "strong" president who would stop the tension in Chechnya (Le, 2006, pp. 129154). They also demanded the resolution of pivotal economic issues, by curbing inflation, developing production, and raising wages (Mozes, 1989; Shubin, 2005).

Although the Kremlin's administrative resources and the money used to pay for Vladimir Putin's election campaign obviously helped determine his victory, his relatively young age and his longtime work as a KGB officer were decisive factors in the 2000 elections. Putin symbolized the "order" long awaited by Russian people and received mass support. However, already in the first years of his tenure, Russia demonstrated ignorance to the democratic principles proclaimed during Gorbachev's perestroika. Strong administrative influence on the mass media was clearly observed during Putin's first tenure (2000-2004), when a number of leading media outlets actually became under state control. During Putin's second presidential term (2004-2008), the Kremlin insistently initiated a sale of the remaining media outlets that maintained a position independent from the government.

Today only a very small number of Russian media can express a position independent of the higher powers. This uniformity of views became noticeable as early as a few years ago, when all Russian TV channels, without exception, began lobbying the interests of the current political regime. This was similar to the Soviet period, under which monopolization of collective consciousness under the aegis of the Communist party was evident. Though a direct comparison of the two periods does not seem to be entirely accurate, due to significant appreciable differences between past and current Russian politics, certain parallels do exist.

Why did the social transformation that began in the Soviet Union 35 years ago not create solid guarantees for political plurality and economic development? Moreover, the initial hopes, repeatedly voiced in Russian society, not only inhibited qualitative changes in the country, but became detrimental to the economy.

Answering the above question is the key to understanding the essence of perestroika and glasnost. We will focus our attention not only on the political situation of Gorbachev's time, but also on the historical development of Russian society, providing additional explanations for why perestroika and glasnost, which began quite optimistically, did not bring sufficient far-reaching results. A look into both the more recent and distant past clearly illuminates the trends and prospects of Russian politics and media. 


\section{Theoretical Background of the Article}

The authors studied numerous scholarly works that have examined the social and political features of perestroika and glasnost as inevitable parts of a lengthy historical process (Matthews, 1989; Mikheyev, 1996; McFaul, 1999; Korotich, 2000; Gaidar, 2020). The focus is the relationship between authorities and society during that time, and the trends that resulted, compared to the USSR's previous political evolution, from 1917 to 1985 (Alexander, 1997; Levada, 2004; Plamper, 2005; Medvedev, 2009; Magun, 2010; Plokhy, 2015). Special attention was paid to the personality of CPSU General Secretary Mikhail Gorbachev as the leader of perestroika and glasnost, and his ideas about the essence and the possibilities of the sociopolitical transformation in the country at the time (Pozner, 1990; Cook, 1993; Gorbachev, 1987, 1988; Ligachev, 2009). Works examining the media's role in this process, as well as the content trends that developed in those years were investigated (McNair, 1991; Vachnadze, 1992; Androunas, 1993; Paasilinna, 1995; Rostova, 1997; Belin, 2001; Richter, 2002; Zassoursky, 2004; Oates, 2009).

\section{Gorbachev's Transformation: Origins and Outcomes}

The idea of transformation, as an integral definition of the words perestroika and glasnost, was proclaimed in April 1985 at the plenum of the Communist Party's Central Committee. "We strive for greater transparency [...] People should know both the good and the bad..." Mikhail Gorbachev, who had become the CPSU General Secretary a month earlier, noted in his report (Gorbachev, 1988, p. 2). Soviet leaders had regularly uttered similar words long before him, but the proclaimed intentions rarely developed. However, under Gorbachev the gradual social renewal began indeed, which eventually led to the country's rejection of the socialist government (Hewett, 1988; Afanasyev, 1991).

Initially, the purpose of perestroika was to propel the country's social and economic development. The reforms were aimed at initiating competitiveness in the Soviet economy, which obviously lagged behind that of the U.S. and other Western European countries (Gaidar, 2020). Glasnost was meant to promote open discussions about the country's various deficiencies. Gorbachev believed that this openness would provide an impetus to further the nation's progress, which could eventually eliminate existing problems (Magun, 2010; Kotkin, 2018). A special mission to advance glasnost was assigned to the media, who had been under strict state control during Soviet times. They were part and parcel of the political system (Mozes, 1989; Androunas, 1993).

The new political course aroused great enthusiasm in Russian society. Gorbachev traveled the country, meeting with people from all strata of society-in scientific institutions and various industries - to get their feedback. Such direct communication between the leader and his people was considered a new political practice which caused a great enthusiasm from the population. It seemed that the crisis in the country brought about by the introduction of glasnost would be quelled quickly, and the Soviet economic system would receive a much-need 
boost. It was apparently necessary to strengthen discipline and to replace negligent leaders; the national system of political and economic management would work eventually.

However, the years of perestroika and glasnost did not bring stable positive changes, and it was clear that Gorbachev and his entourage had misjudged the situation. In the late 1980s, the country increasingly plunged into a large-scale economic crisis gripped by an all-encompassing deficit. Gorbachev's speeches about the need for dynamic development of the country, although true, were increasingly losing their original significance and popularity (Shubin, 2005; Medvedev, 2009).

\section{No National Strategy}

There are several reasons why Gorbachev's initial optimistic plans have not been fulfilled. First, the initiators of the social transformation did not have a well thought-out and trustworthy national strategy to implement their leader's intentions. Gorbachev himself was apparently afraid of the rapid implementation of glasnost. Neither he nor his entourage had experienced discussing pivotal issues openly, tête-à-tête, with the people. They could discuss only convenient topics, not those that emerged in times of crisis. Moreover, the very concept of crisis that engulfed the country in the following years was unusual for them. Therefore, while the USSR's political leadership declared the importance of informing the Soviet population about the country's pressing issues, it did not venture to abolish the party's regulations, including formal censorship. These two seemingly mutually exclusive trends accompanied perestroika and glasnost all those years, before the collapse of the USSR in 1991 and Gorbachev's departure from the political scene (Trudoluybov, 2015).

The existence of good intentions, and the unwillingness of the government to implement them, was most clearly confirmed following the explosion at the Chernobyl nuclear power plant on April 26, 1986. This disaster proved that many of Gorbachev's promises were no more than sloganeering; behind them there was no real readiness to problem solve.

The Chernobyl disaster was the largest nuclear accident in history. In the days that followed, there was total secrecy regarding the explosion. Three days following the disaster, Pravda, the official newspaper of the Communist party at the time, published a short news item about what had happened, but the coverage was so vague that it was impossible to understand the tremendous risk that resulted for people and the environment. Almost two weeks later, on May 7, Pravda published a skewed report from a press conference held by the representatives of the government commission that investigated the reasons and consequences of the accident. On May 14, Gorbachev finally made a personal statement on the country's only TV station, without fully conveying the seriousness of the situation, omitting the consequences of the destruction and the number of human losses. As the media was unable to acquire the necessary information, as it was strictly provided, it too remained silent about the catastrophe. They were also forbidden 
from involving experts in the discussion of the event (Yaroshinskaya, 1992, p. 245).

The same problem concerning the transmission of information became evident during the Armenian-Azerbaijani conflict in Nagorno Karabakh (19871988), caused by the sharp rise of the national movement in these Soviet republics. The conflict turned out to be a consequence of disagreements between the right of the Armenian community living in Azerbaijan to self-governance and the refusal of Azerbaijan to permit Armenians to live on their land (Melik-Shakhnazarov, 2011). Information about the conflict circulated constantly in the Russian central media. However, it consistently reached the audience after a great delay, and was incomplete and biased, depending on the objectives of the political moment. The media frequently preferred siding with Azerbaijan and critically assessing Armenia's position, largely due to the Kremlin's different attitudes toward the leadership of both republics (Androunas, 1993, pp. 20-27; Yumatov, 2013).

Despite decreasing control over the media, Soviet authorities continued restricting journalists' access to information regarding social conflicts. Although glasnost expanded the opportunities for people to know, it did not ensure the implementation of their right to receive timely and reliable information, due to the country's long history of authoritarian rule (Strovsky, 2011, p. 235).

\section{Resistance from the Party}

Another reason why perestroika and glasnost did not ensure sustainable development was because Mikhail Gorbachev and his close entourage, in their efforts to implement sociopolitical and economic changes, were unable to overcome the resistance of the party apparatus. During the implementation of glasnost, many officials felt a threat to their personal security. Even Gorbachev himself, time after time, seriously worried that the civil activity of the population would go beyond "reasonable" limits, and therefore did not always act purposefully to resolve political and social problems. This was noticeable, for example, during social unrests in Kazakhstan (1986), Azerbaijan (1988), Georgia (1989), and in a number of provincial regions. The Soviet leader, fearing negative consequences of what was happening, avoided making operational decisions. Instead of being resolute and thereby outpacing the progress of conflicts, Gorbachev plunged into endless and exhausting discussions, indicating that he was indecisive and had a very poor understanding of many pressing situations. It was as if he were putting many issues into a large box, in the hope that they would somehow resolve themselves. The results, however, tended to be exactly the opposite of what he had expected.

Gorbachev feared losing the party's support during the Lithuanian crisis in January 1991, after Lithuania declared independence from the USSR in March 1990. While Soviet authorities had eagerly sought to delay this process, it was inevitable. As a result, additional military units were sent to Lithuania. Every month, the situation became more and more severe (Vedomosti of the Supreme Council and Government of the Republic of Lithuania, 1990). On January 13, 
1991, the Soviet military carried out the assault against the TV tower in Vilnius, which led to great tragic consequences: 13 people were killed and at least 140 were wounded (BBC, 1991). However, since then, the process of Lithuania gaining independence progressed faster than before. After returning from one of his foreign trips, Gorbachev publicly stated that he was unaware of what was happening, which was certainly far from the truth (Gelaev, 2015). More likely, he eagerly wished to be distant from these social "eruptions," while assuming that, at that time, he would be at risk of losing the confidence of the party.

Situations such as the Lithuania crisis have determined an acute conflict of interests, both within the ruling Communist party, and between officials and society. Whereas under the flux of broadcast information, society openly demanded changes, the highest powers in the country were wary of them and hindered the development of democracy. Yet this stimulated in Lithuania a new round of rejection of the Soviet government and the desire to leave the USSR. For example, following the Lithuania crisis, Gorbachev demanded the suspension of the Media Law (1990) that he had personally approved some time before. He believed that this law remarkably provoked the situation (Rostova, 1997). The lack of eagerness to resolve conflicts such as the Lithuania crisis triggered a collapse that became more apparent only a few months later.

The years of perestroika and glasnost were marked by pronounced social dilemmas. The sudden flood of information uprooted people's previous ideas about everything around them. A significant reason for the "Brownian motion" in the country was the unwillingness of the Soviet republics that were part of the USSR to see Moscow as the main political center as it had been previously. They were increasingly in favor of their own decision-making on major issues, especially multinational, given the majority of non-Russians living in those parts of the country. The Soviet republics did not want the previous system of cadre nominations initiated by Moscow. Consequently, the Kremlin was gradually losing control, and many political and economic initiatives seemingly adopted there for the Soviet republics remained unfulfilled. The country was becoming an endless field for numerous and largely useless discussions, whereas the real development of the USSR looked very uncertain and worrisome with every passing year.

\section{Authoritarian vs Civic Culture}

An even greater problem hindered the transformation into a civic culture in the USSR: the country's extremely strong authoritarian political roots. An authoritarian political culture is characterized by the state's strict control over the country, subordinating all manifestations of social and individual life. The leadership of the main political party consciously undermines any legal opposition. Additionally, the dominance of ideology, centralized subordination of the economy, and the state's monopoly on the media become a priority (Hopkins, 1970; Remington, 1981; Siebert et al. 1984). In turn, a civic political culture emphasizes freedom of spiritual and political relations, no matter how idealistic. It promotes consensus (albeit conditional at times) between state and social interests. 
However, as it maintains the dominant role of the state in resolving major issues, such a culture is likely to generate serious disagreements in society (Almond and Verba, 1963).

Long before the establishment of Soviet power in 1917, Russia professed to the authoritarian ideology. The country was traditionally an absolute monarchy that undermined all other branches of political management, including Parliament, which emerged in Russia only in 1906, much later than in other European countries. "All Muscovites or Russians are content with a more servile state than a free one and are headed by an outstanding guardian whom they consider as their own ruler," wrote Italian historiographer Alexander Guagnini as early as in the 16th century (Kantor, 1998, p. 15). The centuries-old presence of such an authority determined strict centralization of political and economic power. This formed a pronounced way to chiefdom, under which monarchy was crowned as "the anointed of God." In Soviet times, this resulted in the formation of a cult of personality around the leaders of the country.

The lack of rights and freedoms in Russian society led to the suppression of individual opinions. This was significantly different from the dominant attitude in European countries, where the ideas of the emancipation of an individual and plurality in the political and economic spheres was actively propagated and achieved (Strovsky, 2001, pp. 47-48). In Russia, unlike "enlightened Europe," it was not the state that naturally grew out of civil society; rather, society made weak attempts to establish itself under the strict patronage of the state. Active members of the social groups that tended to change the subordination between the state and individuals in Russia had the only means to do so, through cooperation with the state, which meant giving up their own political desires (Pipes, 1974).

All this formed a certain cultural genotype in Russia, affecting the relationship between the citizens and the government. Everything was traditionally controlled not only through law, but also through the efforts of those who were in power. This system in turn created a constantly propagated "mobilization strategy" (Panarin, 1997, pp. 46-49) that stimulated the societal belief that strong efforts can achieve optimal results (Lossky, 1991). It fixed in the collective consciousness the desire for the rapid destruction of previous beliefs, through mass riots and revolutions, and eventually ensured the Bolsheviks' rise to power in 1917.

However, this renewal of the political system did not lead to a changed relationship between the government and society. The methods of this interaction resembled the traditional ones, built on the idea of an "absolutist state" (Leontovich, 1995, pp. 1-4). Greater centralization of powers in the Soviet state led to even more limited freedom of speech and the media, compared to prerevolutionary times (Zimon, 1998, p. 12). As a result, all social life was subjected to a strong dictate that led to stricter totalitarian relations (Arendt, 1951; Đilas, 1957).

The key element of these relations was the existence of a party political system, dominated by the concentration of power and the lack of political competition. All threads of state administration were controlled by the politburo, headed by the General Secretary of the CPSU Central Committee, which built its activities on party ideology. Through this ideology, a prioritization of values was inserted into collective consciousness (such as serving authority, considering the 
state before thinking about oneself, and maintaining loyalty to Communist ideas in all sectors of society). The Soviet management system was considered much more effective compared to such systems in capitalist countries. Various forms of propaganda, including the party press, were used to enlighten the population with their ideas (Buzek, 1964; Choldin, 1985).

Social life in Russia prior to 1917, and later, in the Soviet years, was still more diverse than one might assume from the above description. Science, art, book publishing, etc., were developing continuously. Nonetheless, unified archetypes of collective consciousness and behavior were being formed, including the portrayal of the state as "productive space" for the development of society and individuals, a sacred attitude to powers, and the significance of the printed word, which professed the "only correct" interpretation of facts (Vilkov and Zakharova, 2010, pp. 105129). This created a simplified perception of the world and ensured that any nonstandard initiatives offered in various areas of life progressed with great difficulty. It seemed that the country could not get out of its centuries-old bureaucratic state, and for this reason the technical modernization undertaken by the Soviet leadership in the twentieth century, did not bring changes to the familiar status quo between the government and society (Vishnevsky, 1996, pp. 55-57).

The social transformation that developed under Gorbachev led to dramatic changes. Gorbachev did not seek to destroy the previous values of political subordination; he only intended to preserve the political system in the form that existed throughout the Soviet years. He only wanted to add "a little bit of democracy," leaving the entire political basis unchanged. However, under the rapidly developed glasnost, the country's most pressing political, legal, national, and other issues began coming to the fore. This created serious problems, both within ruling bodies and between the government and society. Glasnost also tackled media content, while previously they were restricted from making true assessments of politics (McFaul, 1999).

Due to the USSR's long-lasting hierarchical system of management, the relationship between the government and society at a new stage of national history turned out to be extremely volatile (Omelichkin, 2015). The rejection of the prior system of subordination began to crumble in 1988; by 1989, it had spun out of control. It was similar to a clock's pendulum that, over many centuries, had been swinging in one direction. However, under the new reality, it abruptly swung in the opposite direction, sweeping away everything on its path.

In the new political environment, the country was unable to form a legislative mechanism for resolving conflicts. Even the rapid adoption of a number of laws that met the current requirements (Law on Cooperatives in 1988, Media Law in 1990, and others, as well as the abolition of article 6 of the Constitution regarding the leadership of the Communist party and the establishment of a multiparty system) did not create a consensus between the government and society. This became a true hindrance toward social transformation in the Soviet Union. 


\section{Media Content}

The media contributed greatly to Russia's social transformation. Having existed under strict subordination to the authorities since 1917, the media suddenly had a new role. New topics stimulated media popularity among local residents, and throughout the world, as well as an increase of publications by 15 to 16 million copies annually. In turn, from 1985 to 1988, the total circulation of all Soviet print media increased by 62.4 million copies (Yesin and Kuznetsov, 2002, pp. 171-172). Simultaneously, the new content contained contradictions and misunderstanding, due to the articles' updated format, which ultimately elicited a contradictory attitude toward the media both from the authorities and society.

Various types of media content were then proposed:

- Soviet history and active debates about the country's future

- Sociopolitical conflicts

- Personal opinions

- Letters and responses to social issues from ordinary people

We will focus briefly on the above media trends.

\section{Soviet History and Active Debates about the Country's Future}

The entire pre-Soviet period, which had been positively perceived in the past, fell into the orbit of mass attention. Through media, especially politically oriented journals, the Russian audience became acquainted with various periods of Soviet history, immediately causing fulminant feedback. Stalin and his entourage were perhaps most actively criticized, compared to later leaders of the country: Nikita Khrushchev, Leonid Brezhnev, and others. Negative assessments even touched Lenin and his staff.

Moscow magazine Ogonyok (Twinkle), edited by Vitaly Korotich, debunked long-term historical myths most prominently. It published historical memoirs about former leaders of the Soviet state, articles on red terror and persecution of the intelligentsia, etc. Ogonyok provided scholars, cultured people, and even immigrants a chance to discuss these topics. The magazine's editorial board sought to present the evolution of the national culture as a whole, not divided in "ours" and "not ours." At that time, such a stance was new. The media wished to know the past in detail, no matter how incongruous it was.

If the initial publications did not affect the foundations of the Soviet political system, later media content became more uncompromising, criticizing the political powers increasingly as time progressed (McNair, 1991). Criticism of the current party leadership became more pronounced. For the first time in many years, the media attempted to depict the Communist party much more honestly and openly than before, and such openness stimulated public interest in the media. They thereby influenced the ongoing political reforms and stimulated public consciousness in Soviet society (Ovsepyan, 2009, p. 12). This approach provoked 
a sharp reaction from the audience, which began criticizing corruption in government bodies and the privileges of officials.

\section{Sociopolitical Conflicts}

The media criticism that grew in Russian society intensified sociopolitical conflicts. These conflicts were often unconnected with media content, however; the very atmosphere in the country facilitated a more open expression of negativism toward the authorities, which was quite exceptional before perestroika. Without overestimation, perestroika affected the whole country. In the summer of 1989, Russia's coal districts were engulfed by a mass strike of miners who were refused their salaries. The media actively covered these events, criticizing officials for slow work. In contrast to the power structures that tried convincing the population that the problems were temporary, many news outlets raised the issue of increasing conflict, foreseeing even greater social upheavals in the future.

\section{Personal Opinions}

The word $I$, rarely used in the media previously, became ubiquitous during this period. Mandatory editorials and information about "achievements in work" led to opinionated content reports, essays, and comments (with headings such as "There is an opinion!", "I ask for the word," etc.). Journalists increasingly freed themselves from ideological dependence on the government, bringing their own assessments to the fore. At the same time, many journalists stated the need to develop democracy, and freedom of speech and of the press. In raising these issues, some reporters became more popular than film actors. Soon journalists of the national media were being perceived in collective consciousness as pseudopoliticians. This eventually led to their association with the power elite of the country in the early 1990s.

\section{Letters and Responses to Social Issues from Ordinary People}

Many editorial offices began perceiving their interaction with their audience as a vital part of their daily work. Letters circulated in the media criticized the country's various shortcomings and discussed issues that were very painful for the Russian people to confront: the dominance of bureaucracy, environmental problems, corruption, etc. The national and local press devoted entire pages to these letters, and people's opinions were also actively voiced on the air. These opinions often assessed everyday reality from different positions, which was new for the time. The "voice of the people" brought a strikingly pronounced diversity to the media content, which only increased interest in the issues being discussed.

Despite external appeal, the abovementioned content trends generated a controversial reaction, both from the authorities and among various strata of Soviet society. A great number of people were not ready for such rapid changes in the information agenda. 
While expanding the existing framework of freedom of information, Soviet journalists did not always take into account the social psychology of the mass audience, its ability to accept the novelty of information influence overnight. The media's harsh, unapologetic assessment of the country's past and present was not morally accepted by many people, which contributed to a rapid split in society. In addition, during those years the media began raising topics that did not fit into traditional values: celebrity lifestyles, crime, etc. However, this enticing content was unreliable, and therefore the media were unable to build stable trust among its mass audience. Trust is formed not only due to an article's cleverness and entertainment value; journalists must feel a responsibility to their audience. The Soviet media were not prepared for this. When defending the priorities of glasnost, they perceived that their main task was to free themselves from the legacy of Russia's past. For this purpose, they used different forms of influence, including sensational information. Constant fluctuations in the media's portrayal of the situation made their position totally unstable and untrustworthy.

\section{Discord}

The main problem with Gorbachev's transformation was not the renewed media information, but the social situation itself. Despite significant sociopolitical changes, the CPSU still had a monopoly on media resources, and its decisions were formally considered as "the only correct ones." For this reason, all doubts about the prospects of socialism or various ways of national development were fiercely dismissed by the political powers themselves. During those years, the idea of socialism "with a human face" suddenly became popular, but it was impossible to understand the meaning of "human face" in relation to the existing political system. While the party allowed the media to present a critical view of the country's past, the party was extremely jealous of the country's present. Gorbachev's utterance at the very beginning of perestroika, that "we have no zones closed to criticism," remained a mere slogan.

As the transformation progressed, the country's economic situation became increasingly precarious. Food was becoming increasingly scarce (Sogrin, 2001). Regions even began switching to a distribution (coupon) system that restricted the population from purchasing certain essential goods: meat, sausage, sugar, butter, etc. All this created uncertainty in the minds of people who could no longer be reassured by Gorbachev's speeches that perestroika and glasnost were "irreversible." Unlike the population of many Western countries, which enthusiastically welcomed Gorbachev during his foreign visits, the Soviet people perceived him more and more reservedly, if not negatively, seeing him as personally responsible for all of the country's problems (FOM, 2016).

Some media were fiercely critical of the ongoing transformation. In an article in Sovetskaya Rossiya (March 1988), by Nina Andreeva, an associate professor at the Leningrad Technological Institute, the writer opposed critics of the Communist system. She argued that Soviet history was marked by many achievements, and 
that mass repressions in the 1930s and 1940s were caused by objective necessity. She fiercely protected Stalin's methods of leadership (Andreeva, 1988).

Individual representatives of the country's leadership did not hide their satisfaction with Andreeva's article. Yegor Ligachev, a member of the CPSU politburo, said the article expressed exactly what he was interested in during those years: the rejection of the reckless undermining of the past. "At that time many noted: Andreeva's article was her reaction to the muddy flow of anti-historical and anti-Soviet materials in our press" (Ligachev, 2009, p. 147). Only a month later, on April 5, 1988, Pravda published an editorial: "Principles of Perestroika: Revolutionary Thinking and Actions," which noted that Andreeva's ideas were completely opposite to those expressed by the Central Committee of the Communist Party headed by Gorbachev.

The conflicting attitude to perestroika was actively growing during those years. Mikhail Gorbachev and his inner circle could no longer stop such attitudes from spreading. Obviously, when initiating the transformation, Gorbachev could not consciously imagine where it would lead. It seemed to him that it was only necessary to "open the door a little" through a "healthy discussion" of problems, and the management system would straighten up and work. Yet the number of political, economic, legal, national, and other problems that were first brought to light was so great that they created a destructive storm that swept away everything in its path.

Along with it, journalists, who had been brought up with the authoritarian ideology, often proved to be completely inflexible in establishing the most important issues. "During the six years of perestroika," Vachnadze (1992, p. 15) fairly pointed out, "the Soviet government and its press tainted themselves with campaigns of silence and direct disinformation. The press still had a long way to go, from glasnost to freedom of information." Today, almost thirty years after these words were articulated, they are still relevant.

In the absence of journalists' ability to work in the new conditions, which required increased responsibility for the word, many articles were so destructive that they seriously hindered the building of constructive relations between actors in sociopolitical conflicts. This was confirmed by Gorbachev's own inability to see the real problems of the transformation.

Consequently, a few of the country's leaders that did not agree with the course of transformation created the State Committee on the State of Emergency (GKChP). In August 1991, the committee planned to remove Gorbachev from power and to take responsibility for further reforms. At the same time, its statements immediately following seizing power confirmed that the GKChP sought to stop many laws passed in previous years and to introduce strict censorship (Plokhy, 2015). Although the GKChP did not receive any public support, its emergence showed that perestroika and glasnost had finally reached an impasse. The social transformation in the second half of the 1980 s led to the collapse of the USSR and the beginning of a new page in the country's history. 


\section{Conclusion}

In the late 1980s, the political situation in Russia was determined by the course of Mikhail Gorbachev's perestroika and glasnost. The sociopolitical processes that took place in the country during those years awakened public consciousness and stimulated the attention of the media, making them full participants amid the changes.

Meanwhile, the changes initiated by Gorbachev were difficult for millions of Soviet people to understand and accept. The proposed transformation formed a new perception of reality, unusual and nontraditional, which created a gradual splitting of society and the formation of small groups with new political interests. The conflict between them was so remarkable that it seemed impossible to overcome it, even in the future. As a result, the issues and difficulties of the social transformation in the USSR were not less noticeable than its achievements. This is the answer to the question raised at the very beginning, why the changes that began in the Soviet Union a few decades ago did not create guarantees for the development of plurality and a steady movement toward market reforms.

Mikhail Gorbachev, who successfully launched perestroika and glasnost, was unable to pass the test of democratic change. At the end of his reign, he became more inclined to the old, conservative methods of leadership, which affected his personal authority: He was losing popularity with every passing month. The leader of the country was tossed between various conflicting actors (new political parties that began appearing, the left and right in the Supreme Council of the USSR, members of the government), ultimately pulling the brake on perestroika and glasnost.

Why did Gorbachev and his entourage fail to implement the ideas that held so much promise? There are a few reasons. First, Gorbachev himself could not overcome the resistance of the Communist party. In fulfilling the ideals of perestroika and glasnost, many officials felt a threat to their personal safety and, one way or another, did not favor the proclaimed reforms. Second, Gorbachev, as a party representative, was concerned that the civil activity of the population does not go beyond the "reasonable," and he therefore did not always act decisively and purposefully. He never once questioned the need for a Communist party, which inevitably held back all political changes that went beyond the ruling ideology. Third, the desire for compromise and "balanced" decisions failed as the economic situation in the USSR worsened, and sociopolitical, interethnic, and other conflicts ensued. Gorbachev often did not have the patience to deal with these issues consistently, and preferred using repressive measures, often relying on the military. This response could not contribute to the formation of public confidence in the country's leader and the ideas that he professed.

Due to numerous clashes in the society-including historical, moral, and multinational issues - many political and economic initiatives remained unfulfilled during the years of perestroika and glasnost. The lack of a well-thought-out national development strategy also impacted the situation. Soviet society did not understand the direction the country was moving in, what its priorities were. The authorities preferred keeping silent, perhaps waiting for instructions from the 
Kremlin — which portrayed vagueness and uncertainty — and were too intimidated to act independently.

The late 1980s were fertile for journalistic creativity. The weakening of political censorship provided a powerful surge in the country's media content. It became more consumed by the mass audience due to promoting more vivid information and a constant dialogue with the readership, which was attractive and made journalists very influential in society. This, however, did not save the country's entire sociopolitical process. The media, as well as society itself, were largely held hostage by the political apparatus, which did not seek to be more open in its decisions. Glasnost meant undermining the government's influence on society, and therefore Soviet officials became the main obstacle to any changes in various spheres of life. While they spoke about the need to change public consciousness, they actually feared these changes because they threatened their personal safety. Only the collapse of the Soviet Union in 1991 brought a real political and economic transformation.

Analyzing perestroika and glasnost can contribute to current and future research of the political science and media in modern Russia, given that contemporary political life there is so similar to its past. The late 1980s comprised the familiar trends of Russian history, as well as contradictions in the relationship between the government, society, and the media. A thorough assessment of that time puts into perspective the country's challenges over the past two decades, under President Vladimir Putin. It also answers the question of why the initial intentions for the development of democracy and pluralism, as proclaimed by the Kremlin, have not evolved successfully: Since the traditional authoritarian experience still remains a stable phenomenon in Russian social life, any profound political changes are illusory and unlikely to be implemented in practice.

\section{References}

Afanasyev, Y. (1991). Ya dolzhen eto skazat': politicheskaya publitsistika vremyon perestroika. (I must say this: political journalism during perestroika). Pik.

Alexander, J. (1997). Surveying attitudes in Russia: a representation of formlessness. Communist and Post-Communist Studies, 30(2), 107-127.

Almond, G., Verba, S. (1963). The civic culture: political attitudes and democracy in five countries. Princeton: Princeton University Press.

Andreeva, N. (1988). Ne mogu postupatsya printsipami. (I can't compromise my principles). Sovetskaya Rossiya, 2.

Androunas, E. (1993). Soviet media in transition: structural and economic alternatives. Praeger.

Arendt, H. (1951). The origins of totalitarianism. Schocken.

Baturin Y., Yegorov V., Kerimov V., Onikov L., Sovokin, A. (1989). Glasnost' $i$ demokratiya. (Glasnost' and Democracy). In V. Afanasyev, G. Smirnova (eds.), Urok Dayot Istorya, 353-375. Politizdat.

BBC (1991). 1991: bloodshed at Lithuanian TV station. BBC News.

Belin, L. (2001). Political bias and self-censorship in the Russian media. In A. Brown (ed.), Contemporary Russian Politics: A Reader, 323-343. Oxford: Oxford University Press. 
Blumler, J. G., Gurevitch, M. (1995). The crisis of public communication. Routledge.

Brown, C. (2017). Conflict studies. SAGE Publications Ltd.

Buzek, A. (1964). How the Communist press works. Pall Mall Press.

Choldin, M. T. (1985). A fence around the empire: Russian censorship of Western ideas and the tsars. Duke University Press.

Coleman, S. (2001). The transformation of citizenship. In B. Axford, R. Huggins (eds.), New Media and Politics, 109-126. SAGE Publications Ltd.

Cook, L. J. (1993). The Soviet social contract and why it failed: Welfare policy and workers' politics from Brezhnev to Yeltsin. Harvard: Harvard University Press.

Đilas, M. (1957). The new class: an analysis of the Communist system. Harcourt Brace Jovanovich.

Featherstone, M., Lash, S. (1995). Globalization, modernity, and the spatialization of social theory: an introduction. In M. Featherstone, S. Lash, R. Robertson (eds.), Global Modernities, 1-24. SAGE Publications Ltd.

FOM (2016). O roli Mikhaila Gorbacheva. (On the role of Mikhail Gorbachev). FOM Russia.

Gaidar, Y. (2020). Gibel' imperii. Uroki dlya sovremennoi Rossii. (The demise of the empire. Lessons for modern Russia). Corpus.

Gelaev, V. (2015). Kak Gorbachev na Litvu sanktsii nalozhil. (How Gorbachev imposed sanctions on Lithuania). Gazeta.

Gorbachev, M. (1987). Perestroika: new thinking for our country and the world. London: Harpercollins.

Gorbachev, M. S. (1988). Perestroika i novoye myshleniye dlya nashei strani i vsego mira. (Perestroika and new thinking for our country and the world). Moskva: Politizdat.

Harvey, D. (1989). The condition of postmodernity: an enquiry into the origins of cultural change. Blackwell.

Hewett, E. A. (1988). Reforming the Soviet economy: equality versus efficiency. Brookings Institution Press.

Hopkins, M. W. (1970). Mass media in the Soviet Union. Pegasus.

Isakov, V. (1998). Raschlenyonka. Kto i kak razvalil Sovetskiy soyuz: khronika. Dokumenti. (Dismemberment. Who and how the Soviet Union collapsed: chronicle. Documents). Zakon I Pravo.

Kantor, V. (1998). Lichnost' $i$ vlast' v Rossii: sotvoreniye katastrofi. (Personality and power in Russia: creating a disaster). Voprosi Philosophyii, (7), 14-22.

Kelle, V. Z., Koval'zon, M. Y. (1981). Teorya i istorya: problem teoryi istoricheskogo protsessa. (Theory and history: problems of the theory of the historical process). Politizdat.

Korotich, V. (2000). Ot pervogo litza. (The first person). ACT.

Kotkin, S. (2018). Predotvrashchenniy armageddon. Raspad Sovetskogo Soyuza, 1970 2000. (Prevented Armageddon. The collapse of the Soviet Union, 1970-2000). Novoye Literaturnoye Obozreniye.

Lamazhaa, C. K. (2011). Sotsialnaya transformatsya. (Social transformation). Encyclopedia Gumanitarnich Nauk, (1), 262-264.

Le, E. (2006). The spiral of "anti-other rhetoric": discourses of identity and the international media echo. John Benjamins Publishing Company.

Leontovich, V. (1995). Istoriya liberalizma v Rossii, 1762-1914 [History of liberalism, 1762-1914]. Russky Put'.

Levada, Y. (2004). "Chelovek Sovetskiy": chetvyortaya volna. Ramki samoopredeleniya. ("The Soviet Man": the fourth wave. The limits of self-determination). Vestnik Obshchestvennogo Mneniya, 3(71), 8-18.

Ligachev, Y. (2009). Kto predal SSSR? (Who betrayed the USSR?) Eksmo. 
Lossky, N. O. (1991). Kharacter Russkogo naroda. (The character of the Russian people). Biblioteka Elektronnoi Literature.

Magun, A. (2010). Perestroika kak ronservativnaya revolutsiya. (Perestroika as a conservative revolution). Emergency Ration: Debates about Politics and Culture, 6(74), 231-249.

Martinelli, A. (2012). Global modernization: rethinking the project of modernity. SAGE Publications Ltd.

Matthews, M. (1989). Patterns of deprivation in the Soviet Union under Brezhnev and Gorbachev. Hoover Institution Press.

McFaul, M. (1999). Lessons from protracted transition from communist rule. Political Science Quarterly, 114(1), 103-30.

McNair, B. (1991). Glasnost, perestroika and the Soviet media. Routledge.

Medvedev, R. (2009). Sovetskiy Soyuz: posledniye gody zhizni. (The Soviet Union: the last years of life). Vremya.

Melik-Shakhnazarov, A. (2011). Nagorniy Karabakh; khroniki nenavesti. (Nagorniy Karabakh: chronicles of hatred). Sovremennaya Shkola.

Mikheyev, D. (1996). Russia transformed. Hudson Institute.

Mozes, J. C. (1989). Democratic reform in the Gorbachev era: dimensions of reform in the Soviet Union. The Russian Review, 48(3), 235-269.

Oates, S. (2001). Politics and the media. In S. White, A. Pravda, Z. Gitelman (eds.), Developments in Russian Politics, 254-268. Palgrave.

Oates, S. (2009). The neo-Soviet model of the media. In B. Beumers, S. Hutchings, N. Rulyova (eds.), Globalisation, Freedom and the Media after Communism: The Past as Future, 37-55. Routledge.

Omelichkin, O. (2015). Grazhdanskaya kul'tura Rossii: problem formirovaniya. (Civic culture of Russia: the problems of formation). Vestnik Kemerovskogo Gosudarstvennogo Universiteta, 2(62), 76-80.

Ovsepyan, R. P. (2009). Publitsistika epokhi poiska i nadezhdi. (Journalism of the age of search and hope). In Istorya Otechestvennoi Zhurnalistiki: Pervaya Polovina 80-kh Godov XX Veka: Khrestomatya. Moscow State University.

Paasilinna, R. (1995). Glasnost and Soviet television: a study of the Soviet mass media and its role in society from 1985 to 1991. Yleisradio.

Panarin, A. (1997). Rossiyskaya politicheskaya kul'tura: prognozi na XXI vek. (Russian political culture: forecasts for the twenty-first century). Vlast', (11).

Pipes, R. (1974). Russia under the old regime. Charles Scribner's Sons.

Plamper, J. (2005). Cultural production, cultural consumption: post-Stalin hybrids. Kritika: Explorations in Russian and Eurasian History, 6(4), 755-762.

Plokhy, S. (2015). The last empire: the final days of the Soviet Union. Basic Books.

Pozner, V. (1990). Parting with illusions. Atlantic Monthly Press.

Remington, T. (1981). The mass media and public communication in the USSR. The Journal of Politics, 43(3), 115-154.

Richter A. (2002). Media regulation: foundation laid for free speech. In K. Nordensreng, E. Vartanova, J. Zassoursky (eds.), Russian Media Challenge, 115-154. Kikimora Publications.

Rostova, N. (1997) Rastsvet rossiiskih SMI. (The rise of Russian media). Yeltsin Media.

Sazanov, D. (2012). Transformatsiya obshchestvenno-politicheskogo soznaniya sovetskoi intelligentsia. Izhevsk, Russia : Udmurt State University.

Shubin, A. (2005) Paradoksi perestroiki: neispol'zovanniy shans SSSR. (Paradoxes of perestroika: an unused chance of the USSR). Moscow: Veche. 
Siebert, F. S., Peterson, T., Schramm, W. (1984). Four theories of the press: the authoritarian, libertarian, social responsibility and Soviet Communist concepts of what the press should be and do. Illinois: University of Illinois Press.

Sogrin, V. (2001) Politicheskaya istoriya sovremennoi Rossii. 1985-2001: ot Gorbacheva do Putina. (Political history of modern Russia. 1985-2001: from Gorbachev to Putin). Ves Mir.

Strovsky, D. (2001). Otechestvennye politicheskiye traditsii $v$ zhurnalistike sovetskogo perioda. (Native political traditions in journalism of the Soviet period). Ural State University.

Strovsky, D. (2011). Otechestvennaya zhurnalistika noveishego perioda. (Native journalism of the modern period). UNITY-DANA.

Trudoluybov, M. (2015). Ot glasnosti k bezglasnosti. (From glasnost to non-glasnost). Vedomosti.

Turpin, J. (1995). Reinventing the Soviet self: media and social change in the former Soviet Union. Praeger.

Vachnadze, G. (1992). Sekreti pressi pri Gorbacheve i Yeltsine. (Secrets of the press under Gorbachev and Yeltsin). Kniga I Biznes.

Vedomosti of the Supreme Council and Government of the Republic of Lithuania (1990). Address of the Supreme Council of the Republic of Lithuania from 22.03.1990: to the peoples, governments and people of goodwill of the world, 394-395. Vedomosti of the Supreme Council and Government of the Republic of Lithuania.

Vilkov, A., Zakharova, T. (2010). Sakral'niye osnovaniya v povsednevnoi zhizni Rossii. (Sacral frameworks of the powers in Russia's political life). Nauka.

Vishnevsky, A. (1996). Konservativnaya revolutsiya $v$ SSSR. (The conservative revolution in the USSR). Mir Rossyi, (4), 3-66.

Yaroshinskaya, A. (1992). Chernobyl': sovershenno sekretno. (Chernobyl: totally secret). Drugiye Berega.

Yesin, B., Kuznetsov, I. (2002). Trista let otechestvennoi zhurnalistiki. (Three hundred years of native journalism). Moscow: Moscow State University.

Yumatov, K. (2013). Rol' sredstv massovoi informatsii $v$ nagorno-karabakhskom konflikte. (The media role in nagorno-Karabakh conflict). Vestnik Surgutskogo Gosudarstvennogo Pedagogicheskogo Universiteta, 4(25), 149-155.

Zassoursky, I. (2004). Media and power in post-Soviet Russia. M. E. Sharpe.

Zimon, G. (1998). Zametki o politicheskoi kul'ture v Rossii. (Notes on political culture in Russia). Moscow: Lichnost' i vlast': mezhkul'turniy dialog. 